\title{
Retailers' Socially Responsible Communication in the Situation of Global Pandemic
}

\author{
Iveta Linina ${ }^{1, *}$, and Velga Vevere $^{2}$ \\ ${ }^{1}$ Turiba University, 68 Graudu street, Riga LV-1058, Latvia \\ ${ }^{2}$ EKA University of Applied Sciences, 1/5 Lomonosova street, Riga LV-1019, Latvia
}

\begin{abstract}
.
Research background: Retail industry plays an important role in today's society and in the national economy as a whole, as it introduces and develops new technologies in customer service, provides jobs and increases the level of public welfare. Adaptation to the emergency situation, to the customer needs and requirements provide the company with opportunities for further development and increase of competitiveness, but, at the same time, creates the need to organize customer service, the efficient use of existing resources to manage customer service process. The pandemic of Coronavirus has affected the global economy immensely, the long-term effects are to be seen in the foreseeable future. One of the spheres, among others, hit hard is the retail trade since due to the quarantine conditions there is an inevitable drop in sales (less number of customers means less profit inevitably) and growing competition among retailers. However, the current situation forces retailers to look for innovative, at the same time socially responsible, forms of communication, particularly in social media.

Purpose of the article: To research the evaluation of retailers' socially responsible communication by consumers.

Methods: Expert survey, consumer online survey $(\mathrm{n}=388)$ applying 5point Likert scale, data processing was carried out by SPSS.

Findings \& Value added: By socially responsible communication, a company can build strong relationships with customers and increase their loyalty despite the circumstances
\end{abstract}

Keywords:, social media communication; retailing; customer relationship management; pandemic

JEL Classification: $F 1 ; F 6 ; M 1 ; M 3$

\footnotetext{
* Corresponding author: iveta.linina@turiba.lv
} 


\section{Introduction}

Retail industry plays an important role in today's society and in the national economy as a whole, as it introduces and develops new technologies in customer service, provides jobs and increases the level of public welfare. Adaptation to the emergency situation, to the customer needs and requirements provide the company with opportunities for further development and increase of competitiveness, but, at the same time, creates the need to organize customer service, the efficient use of existing resources to manage customer service process. Consumer satisfaction and its management have become the cornerstone of business competitiveness and an integral part of business. Social networks, in particular, can today become a tool for targeted consumer awareness formation, as entrepreneurs become more effective regarding marketing activities and communications, and consumers become more educated and selective. Market globalization also affects retail businesses, the smaller retailers can become competitive.

The pandemic of Coronavirus has affected the global economy immensely, the longterm effects are to be seen in the foreseeable future. One of the spheres, among others, hit hard is the retail trade since due to the quarantine conditions there is an inevitable drop in sales (less number of customers means less profit inevitably) and growing competition among retailers. At the same time these new circumstances compel retail enterprises to develop new modes communication and new online sales points, since a number of retailers/consumer goods companies have shifted their focus to online sales in view of a surge in consumers' willingness to spend online during the outbreak. [1] The crisis has accentuated the significance of online communication with customers, more specifically, communication of social responsibility (in relation to environment, customers and community). At the same time, it has to be taken into account that the pandemic situation changes and will change the very landscape of the retailing industry. It can be predicted with a cautious certainty, that some of the pandemic caused customer behavioural patterns and trends would stay afterwards (for instance, new distribution channels, customer service, delivery systems, etc.). In order to be ready for the future changes, it is necessary to carry out a research on customer attitudes towards retailers' online communication activities during the pandemic circumstances.

This accounts for the research question proposed in the current research: How do consumers evaluate retailers' online communication during Covid-19 pandemic?

\section{Literature review}

The background literature of the current research can be divided in two broad categories the first concerning the effects of Covid-19 pandemic upon retailing industry (taking into account the fact that it is ongoing process with hardly foreseeable outcome as yet); while the second relating to the retailers' online communication in building and maintaining consumer loyalty.

The most general view upon the Covid-19 impact upon economy can be described as changes in the marketing philosophy. According to Hea and Harris [2] there are several areas most affected by the pandemic crisis. First of them - marketing environment. If preCovid, marketers were fixated on the effectiveness of their value-capturing from customers in the form of customer loyalty, share of the market/customer, and customer equity, then post-pandemic marketers will have to take into account more and more such incontrovertible metrics as customer lifetime value, share of customer, and customer equity. The second one regards changes in the nature of the interaction and exchange: the 
dominance of face-to-face interactions and exchange are being partly of fully replaced by online interactions. Besides that, the authors mention sudden and radical disruptions in the companies' micro-environment. The ways in which companies operate have been altered by social distancing and forced lockdowns that necessitate radical changes to operations and set-ups. The supply chain globally was largely severed during lockdown and local supply-chains stretched to breaking-point across most industries and sectors. Another element to that organizations will need to acknowledge is the partial failure or pausing of globalization. In their turn, Roggevee and Sethuraman [3] pay attention to changes in the consumption patterns: retailers have to think how to make online shopping more similar to in-person shopping in order to encourage impulse purchasing), as well as they have to rethink about repositioning and promoting the luxury brands and reorganizing the in-store experiences (healthy and sterile environment instead of entertainment).

The systematic summary of problems and retailers' outlook can be found in the edition of "COVID - 19. Industry Pulse Report: Retail." [4] Let us mention here a few main conclusions (although the report regards the state of Cyprus, the conclusions can be extrapolated to the whole industry): (1) majority of retailers have embraced flexibility and reconfigured operations; (2) supply chain problems include temporary shortages for food retailers; delays in production, distribution and stock issues with long lead times for nonfood suppliers; (3) most retailers agree that technology and data analytics are vital for management decisions especially in times of uncertainty; (4) many retailers have increased their online banking features to improve user-friendliness and accommodate increase in traffic; and (5) retailers agree on the need to invest in online channels for business continuity reasons.

Transformations of the retail sphere have been discussed also by Dannenberg and others [5] (they investigate the sharp increase of online sales in food retailing caused by the pandemic), Sun and others [6] (in relation to threat of selling fake goods and forgeries), Desmichel and Kocher [7] (on the promoting of hedonic shopping experience of luxury goods), Abbruzzese and others [8] (the authors' discuss what life habits are to be regarded as 'new normal', i.e. existing almost exclusively online).

In relation to the second are of the conceptual framework, i.e., the employment of social networks by retailers, we have to admit that the literature in the field covers quite broad spectrum of issues - from the role of consumer references and the rewarding engagement strategies, from the electronic word of mouth (e-WOM) and creation of online communities to the online communication strategies. $[9 ; 10 ; 11 ; 12 ; 13]$ Thus, Rehnen and others [14] and Lekhanva [15] have devoted their research to the consumer engagement, particularly. They concluded that although the rewarding per se could enhance the consumer loyalty there existed a danger that offering rewards might make consumers undermine the value of the product in question. Sashi [16], in his turn, created a consumer engagement model consisting of seven stages: connection, interaction, satisfaction, retention, loyalty, advocacy, and engagement. All in all these stages were based on two pillars - interaction and emotional attachment, that by definition accords to the definition of social media as the collective of online communications channels dedicated to community-based input, interaction, content-sharing and collaboration. [17] Consumers are adopting increasingly active roles in co-creating marketing content with companies and their respective brands. In turn, companies and organizations are looking to online social marketing programs and campaigns in an effort to reach consumers where they 'live' online. [18] Word of mouth marketing within s-commerce referred to the sharing of opinions and feedbacks regarding products. This process, when monitored by the company, can play a significant role in the consumer loyalty enhancement, especially when, there is a high level of competition represented by products that are rapidly introduced to the market. [19] Karjaluoto and others [20] are interested in examine how customer's intention to post WOM can influence 
his/her repurchase intention. Our age of digital media makes the shopping experience entirely different - instead of visiting shopping sites physically modern consumers check retailers' websites beforehand. In the presence of social media, some businesses offer virtual tours of their retail outlets that can provide potential shoppers with guides to convenience features such as parking and opening hours; helping customers to make decisions to frequent certain shopping destinations. Besides that, the websites allow potential buyers immerse themselves in the previous customers' experiences, as well as to leave their feedback afterwards. [21;22]

Still, the most important conclusion, in our opinion, to be derived from the theoretical literature regarding the role of online communication in creating retailer-consumer relationship are the following: the modern consumption patterns require from retailers pay attention to the pre-purchase (information about produce, store opening hours, client service, etc.) and post-purchase (consumer feedback, warranties, etc.) communication.

\section{Methods}

Consumer and consumer behaviour surveys are used to study consumer attitudes and purchasing behaviour. In this study, a traditional method was used to directly and indirectly evaluate the activities of retail companies in the most popular social networks in Latvia - a questionnaire survey.[23] The survey was conducted in Latvia to identify customer satisfaction with retailers' online communication and rank them in order of importance. The preparation of this method involves several steps.

First. Determining the degree of standardization and openness of the questionnaire. Given the purpose of the survey and the characteristics of the respondents, the authors chose a standardized open questionnaire. This means that all respondents were asked the same questions in the same sequence, which ensures an objective comparison of the answers. The questions were selected with a single-choice 5-point Likert scale.

Second. Defining the survey method. Out of all possible options - personal interview, mail survey, phone, fax, email and internet, the authors chose the following - the survey was created on the Google Forms website. Questionnaire with the random sample snowball method [24], via personal contacts of the authors of the work, was sent via e-mail to the respondents who further shared this link. 388 completed questionnaires were considered valid for the study. All residents of Latvia in 2019 were taken as general population. At $95 \%$ confidence level and 5\% error margin, the minimum sample size was estimated at 385 respondents. [25]

An expert survey $(n=9)$ was conducted in May-June 2020. Based on the objectives of the study, per centage of indicators was calculated, then using the SPSS program, the authors calculated the following indicators:

- arithmetic mean expert evaluation $\left(\mathrm{X}^{\overline{ }}\right)$;

- median (Me);

- mode (Mo);

- amplitude of variation;

- standard deviation;

- coefficient of variation.

Afterwards the authors proceeded with data processing and interpretation. 


\section{Results and discussion}

The first question was asked whether the respondents had noticed the activities of the retail companies in social networks related to the Covid-19 emergency. Here, respondents were given opportunity to choose one of two answer options. $89 \%$ of respondents had answered that they had observed these activities, but 11\% had not observed them (see Figure 1).

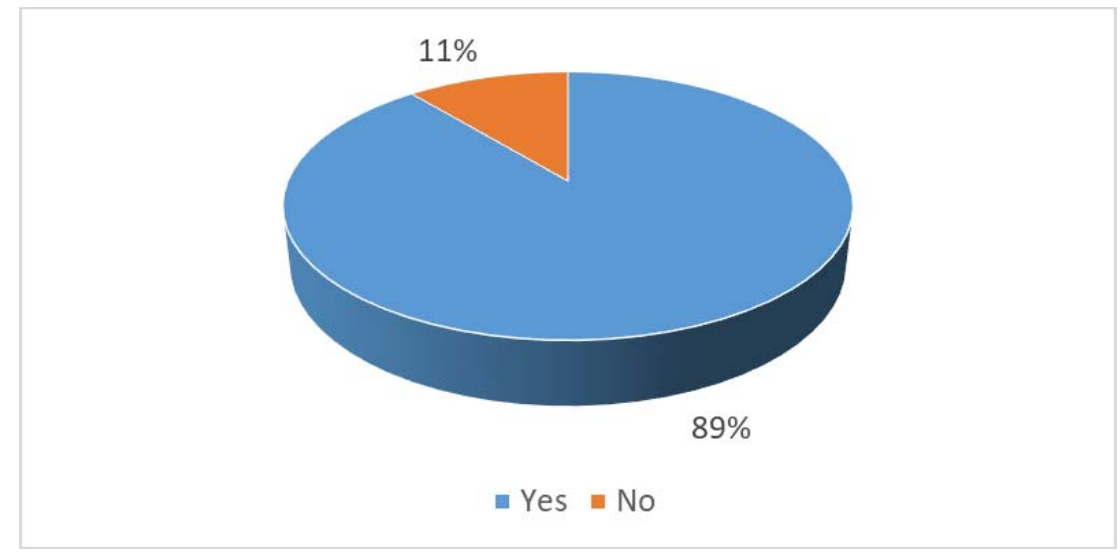

Fig. 1. The activities of trade companies on social media observed by buyers in connection with Covid-19

In the second question, the respondents assessed the activities of trading companies in social networks related to the emergency situation in Covi-19 (in the scale from 1 to 5) (see Figure 2).

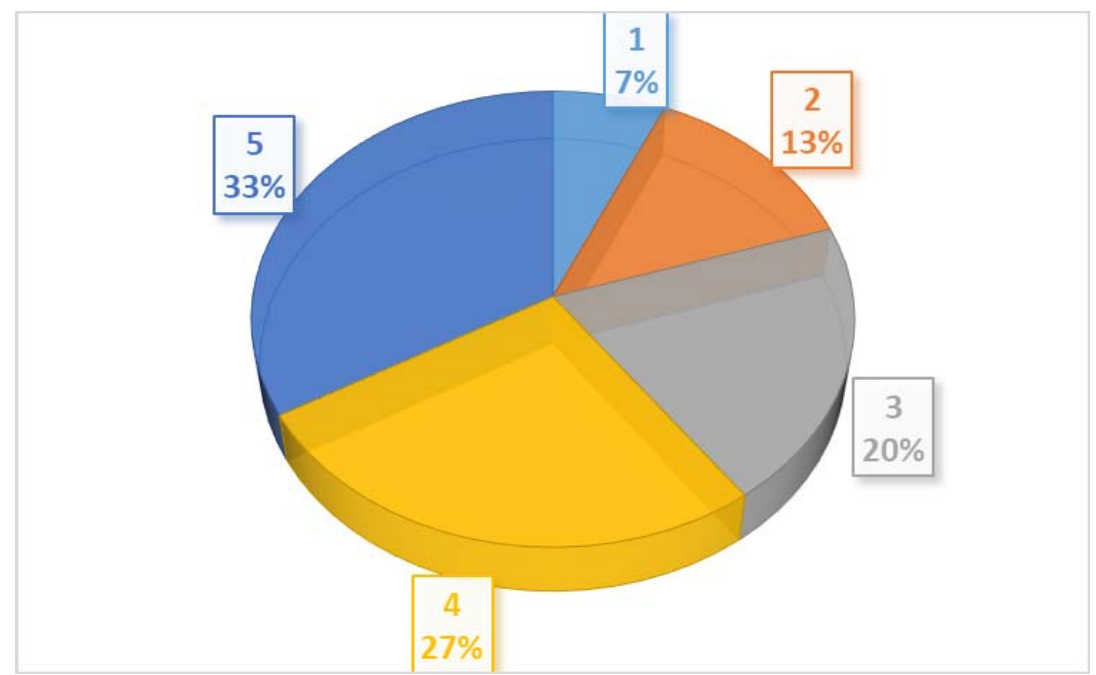

Fig. 2. Retailers' communication related to Covid-19 assessment by consumers

$33 \%$ of respondents have rated the communication of trade companies on social networks in connection with the emergency situation in the aspect of Covid-19 with the highest rating $5,27 \%-4,20 \%-3$, but only $13 \%$ for 2 and $7 \%-1$. This result can be assessed as very high and indicates a high social responsibility of retail companies. 
In order to assess the situation in the activities of retail enterprises in social networks in the conditions of Covid-19, the authors of the paper performed a in-depth data analysis of the survey results (see Table 1).

Table 1. Communication evaluation of the largest Latvian retail store networks in social networks under Covid-19 conditions

\begin{tabular}{|c|c|c|c|c|c|c|c|c|c|}
\hline 矛 & 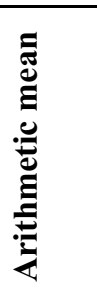 & 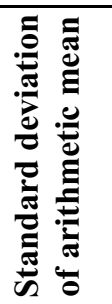 & 节 & $\frac{0}{\stackrel{0}{0}}$ & 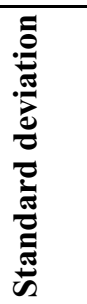 & 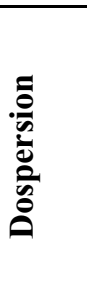 & & $\dot{\Xi}$ & $\sum_{\Sigma}^{\dot{\Sigma}}$ \\
\hline $\begin{array}{c}\text { Rimi } \\
\text { Latvi } \\
\text { a }\end{array}$ & 4.15 & 0.05 & 5.00 & 5.00 & 1.07 & 1.14 & 0.06 & 1 & 5 \\
\hline $\begin{array}{c}\text { Maxi } \\
\text { ma } \\
\text { Latvi } \\
\text { a }\end{array}$ & 3.55 & 0.05 & 4.00 & 4.00 & 0.99 & 0.97 & 0.06 & 1 & 5 \\
\hline Depo & 2.72 & 0.05 & 3.00 & 3.00 & 1.10 & 1.21 & 0.09 & 1 & 5 \\
\hline
\end{tabular}

As can be seen, the lowest rating $\left(\mathrm{X}^{-}=2.79 ; \mathrm{Me}=3.0 ; \mathrm{Mo}=3.00\right)$ was assigned to Depo. The data in Table 1 also show that the retail chain Maxima Latvia achieved a much higher result $\left(\mathrm{X}^{-}=3.55 ; \mathrm{Me}=4.00 ; \mathrm{Mo}=4.00\right)$. The communication of the retail store chain Rimi Latvia with consumers under the Covid-19 situation $\left(\mathrm{X}^{-}=4.15 ; \mathrm{Me}=5.00\right.$; Mo $=5.00$ ) received a much higher rating. In general, it should be noted that the overall assessment of business activities is above average, which indicates the information obtained by consumers is satisfactory; consumers recognized the relevance of information in a crisis situation. Those companies that were rated lower should definitely evaluate quality of their communication in social media and plan for its future improvements.

\section{Conclusions}

1. $89 \%$ of respondents have noticed activities of the retail companies in social networks in connection with the emergency situation related to Covid-19, but $11 \%$ have not noticed them.

2. Evaluating the communication of the largest Latvian retail companies in connection with Covid-19 in social networks, 33\% of respondents rated 5, 27\% $4,20 \%-3$, but only $13 \%$ on 2 and $7 \%-1$.

3. In order to assess the situation in the activities of retail companies in social networks under conditions of Covid-19, the 3 largest retail store chains Rimi Latvia, Maxima Latvia and Depo were examined. The lowest rating $\left(\mathrm{X}^{-}=2.79\right.$; $\mathrm{Me}=3.0 ; \mathrm{Mo}=3.00$ ) was received by the company Depo in communication on social networks. The retail chain Maxima Latvia achieved a much higher result $\left(\mathrm{X}^{-}\right.$ $=3.55 ; \mathrm{Me}=4.00 ; \mathrm{Mo}=4.00)$. The communication of the retail store chain Rimi Latvia with consumers under Covid-19 situation $\left(\mathrm{X}^{-}=4.15 ; \mathrm{Me}=5.00 ; \mathrm{Mo}=\right.$ 5.00) received a much higher rating. In general, it should be noted that the overall assessment of business activities is above average, which indicates the information 
obtained by consumers was satisfactory and its role in a crisis situation was regarded as relevant.

\section{References}

1. PricewaterhouseCoopers. (2020). Weathering the economic impacts of Coronavirus: How can retailers/consumer goods companies turn crisis into opportunities? Retrieved from https://www.pwccn.com/en/industries/retail-and-consumer/publications/impactsof-coronavirus-turn-into-opportunities.html

2. Hea, H., Harris, L. (2020). The impact of Covid-19 pandemic on corporate social responsibility and marketing philosophy. Journal of Business Research, 116, 176-182.

3. Roggeveen, A. L., Sethuraman, R. (2020). The impact of Covid-19 pandemic on corporate social responsibility and marketing philosophy. Journal of Retailing, 96(2), 169-171.

4. COVID - 19. (2020). Industry Pulse Report: Retail. Retrieved from https://assets.ey.com/content/dam/ey-sites/ey-com/en cy/covid-19-updates/ey-covid19-pulse-report-retail-final.pdf

5. Dannenberg, P., Fuchs, M., Riedler, T., et al. (2020). Digital Transition by COVID-19 Pandemic? The German Food Online Retail. Tijdschrift Voor Economische En Sociale Geografie, 111(3), 543-560.

6. Sun, J., Zhang, X., Zhu, Q. (2020). Counterfeiters in Online Marketplaces: Stealing Your Sales or Sharing Your Costs. Journal of Retailing, 96(2), 189-202.

7. Desmichel, P., Kocher, B. (2020). Luxury Single- versus Multi-Brand Stores: The Effect of Consumers' Hedonic Goals on Brand Comparisons. Journal of Retailing, 96(2), 203-219.

8. Abbruzzese, J., Ingram, D., Click, S. (28th March, 2020). The coronavirus pandemic drove life online. It may never return: What passes for normal life now happens almost entirely online. Retrieved from https://www.nbcnews.com/tech/internet/coronaviruspandemic-drove-life-online-it-may-never-return-n1169956

9. Ali, Z., Shabbir, M. A., Rauf, M., and Hussain, A. (2016). To Assess the Impact of Social Media Marketing on Consumer Perception. International Journal of Academic Research in Accounting, Finance and Management Sciences, 6(3), 69-77.

10. Leonardi, P.M., Huysman, M., Steinfield, C. (2013). Enterprise Social Media: Definition, History, and Prospects for the Study of Social Technologies in Organizations. Journal of Computer-Mediated Communication, 19, 1-19.

11. Poturak, M., Softić, S. (2019). Influence of Social Media Content on Consumer Purchase Intention: Mediation Effect of Brand Equity. Eurasian Journal of Business and Economics, 12(23), 17-43.

12. Pütter, M. (2017). The Impact of Social Media on Consumer Buying Intention. Journal of International Business Research and Marketing, 3(1), 7-13.

13. Schivinski, B., Dabrowski, D. (2014). The effect of social media communication on consumer perceptions of brands. Journal of Marketing Communications, 22(2), 1-26.

14. Rehnen, L. M., Bartsch, S., Kull, M., Meyer, A. (2017). Exploring the impact of rewarded social media engagement in loyalty programs. Journal of Service Management, 28(2), 305-328. 
15. Lekhanya, L.M. (2013). The use of social media and social networks as the promotional tool for rural small, medium and micro enterprises in KwaZulu-Natal. International Journal of Scientific and Research Publications, 3(7), 1-7.

16. Sashi, C. M. (2012). Customer engagement, buyer-seller relationships, and social media. Management decision, 50(2), 253-272.

17. Neti, S. (2011). Social media and its role in marketing. International Journal of Enterprise Computing and Business Systems, 1(2), 1-15.

18. Hanna, R., Rohm, A., Crittenden. (2011). We're all connected: The power of the social media ecosystem. Business Horizons, 54(3), 265-273.

19. Kaplan, A.M., Haenlein, M. (2010). Users of the world, unite! The challenges and opportunities of Social Media. Retrieved from http://aisel.aisnet.org/confirm2018/49

20. Karjaluoto, H., Munnukka, J., Tikkanen, A. (2014). Are Facebook Brand Community Members Really Loyal to the Brand? Retrieved from: https://pdfs.semanticscholar.org/5229/037a2d7540f84c8749b296536c666151dd5d.pdf

21. Villarejo-Ramos, A. F., Sanchez-Franco, M. J., Garcia-Vacas, E. M., Navarro-Garcia, A. (2014). Modelling the Influence of eWOM on Loyalty Behaviour in Social Network Sites. In: Strategies in E-Business (pp. 11-28). New York: Springer.

22. De Keyzer, F., Dens, N., De Pelsmacker, P. (2019). The impact of relational characteristics on consumer responses to word of mouth on social networking sites. International Journal of Electronic Commerce, 23(2), 212-243.

23. Rust, R., Lemon, K., Zeithaml, V. (2004). Return on Marketing: Using Customer Equity to Focus Marketing Strategy. Journal of Marketing, 68, 109 - 127.

24. Kristapsone, S. (2014). Zinātniskā pētniecība studiju procesā. Rīga: Biznesa augstskola "Turība".

25. Arhipova, I., Bāliṇa, S. (2006). Statistika ekonomikā un biznesāa. Rīga: Datorzinību centrs. 